\title{
The water footprint of Indonesian provinces related to the consumption of crop products
}

\author{
F. Bulsink, A. Y. Hoekstra, and M. J. Booij \\ Twente Water Centre, University of Twente, Enschede, The Netherlands \\ Received: 9 July 2009 - Published in Hydrol. Earth Syst. Sci. Discuss.: 24 July 2009 \\ Revised: 22 December 2009 - Accepted: 29 December 2009 - Published: 18 January 2010
}

\begin{abstract}
National water use accounts are generally limited to statistics on water withdrawals in the different sectors of economy. They are restricted to "blue water accounts" related to production, thus excluding (a) "green" and "grey water accounts", (b) accounts of internal and international virtual water flows and (c) water accounts related to consumption. This paper shows how national water-use accounts can be extended through an example for Indonesia. The study quantifies interprovincial virtual water flows related to trade in crop products and assesses the green, blue and grey water footprint related to the consumption of crop products per Indonesian province. The study shows that the average water footprint in Indonesia insofar related to consumption of crop products is $1131 \mathrm{~m}^{3} / \mathrm{cap} / \mathrm{yr}$, but provincial water footprints vary between 859 and $1895 \mathrm{~m}^{3} / \mathrm{cap} / \mathrm{yr}$. Java, the most waterscarce island, has a net virtual water import and the most significant external water footprint. This large external water footprint is relieving the water scarcity on this island. Trade will remain necessary to supply food to the most densely populated areas where water scarcity is highest (Java).
\end{abstract}

\section{Introduction}

Governments usually formulate national water plans by looking how to satisfy water users. Even though governments nowadays consider options to reduce water demand in addition to options to increase supply, they generally stick to a water-user perspective, with farmers, industries and drinking water supply utilities as the main water users. It has been argued that the scope of water management should be extended by adding a consumer and trade perspective to the analysis (Hoekstra and Chapagain, 2008). The consumer perspective

Correspondence to: A. Y. Hoekstra (a.y.hoekstra@utwente.nl) takes the view that all water resources use ultimately links to consumption by final consumers and that consumption patterns are thus a key factor in water management as well. The trade perspective takes the view that trade in water-intensive products relieves the pressure on water-scarce regions that import those products and enhances the pressure on the water resources in the exporting regions and that trade is thus a key factor in water management too. Adding the consumer and trade perspectives to the traditional producer perspective would imply that basic water-use accounts need to be extended.

National accounts on water use are usually limited to accounts of the water withdrawal needs in the domestic, agricultural and industrial sector. The water-withdrawal indicator, however, does not give information about the actual need of water by people in relation to their consumption. The indicators of "water footprint" and "virtual water trade" are a useful addition to the water-withdrawal indicator. The water footprint is a consumption-based indicator of water use introduced by Hoekstra (2003). This indicator shows the water use of inhabitants of a country or province in relation to their consumption pattern. The water footprint of the people in a province is defined as the total amount of water that is used to produce the goods and services consumed by the inhabitants of the province. This water footprint is partly inside the province itself (the internal footprint) and partly presses somewhere else (external footprint). Virtual-water trade refers to the transfer of water in virtual form from one place to another as a result of product trade. Virtual water refers to the volume of freshwater embedded in a product; it is the volume of water that was consumed or polluted in the production phase of the product.

This paper shows how national water-use accounts can be extended by including accounts of interprovincial and international virtual water flows and provincial water footprints. This is done through an example for Indonesia. Indonesia has a tropical climate with abundant rainfall. The lowlands

Published by Copernicus Publications on behalf of the European Geosciences Union. 
experience high temperatures throughout the year (averaging $28^{\circ} \mathrm{C}$ ); the inland highlands are somewhat cooler. The eastern monsoon brings the dry season (June-September), while the western monsoon brings the wet season (DecemberMarch). The agricultural sector in Indonesia faces an increasing demand for agricultural products, caused by a growing population and hence a higher consumption (ADB, 2006). Water resources for agricultural activities are getting scarcer due to the growing demand for irrigation. Moreover, competition over water is growing due to an increasing use of water for households and industries (Ministry of Agriculture, 2006). The water use is already highly constrained by unbalanced conditions of demands and the potential availability, particularly during the dry season. The water resources conditions in Indonesia have come to the stage where integrated action is needed to reverse the present trends of overconsumption, pollution and the increasing threat of drought and floods (World Water Council, 2003).

The aim of the study is to quantify interprovincial virtual water flows related to trade in crop products and determine the water footprint related to the consumption of crop products per Indonesian province. The water footprint will be calculated as an average for the years 2000 to 2004 and in the period of analysis Indonesia consisted of 30 provinces. The most important crops for this study have been selected, based on estimated and reported water use, production value and land use. This selection resulted in the following list of crops: rice, maize, cassava, soybeans, groundnuts, coconuts, oil palm, bananas, coffee and cocoa. The selected crops represent $86 \%$ of the total water use, $71 \%$ of the production value and $86 \%$ of the total agricultural land.

The study basically follows the methodology as set out by Hoekstra and Chapagain $(2007,2008)$. Their study was a global study covering nearly all countries of the world. Indonesia was also included in their study, but without going down to provincial level. Research on a more detailed scale has already been done for some countries, such as China (Ma et al., 2006), India (Verma et al., 2009; Kampman et al., 2008), the Netherlands (Van Oel et al., 2008) and the UK (Chapagain and Orr, 2008). These national studies give a more detailed view of the water flows, water use for crop production and water consumption by the population within a country than the global study of Hoekstra and Chapagain could do. After the above-mentioned case studies for China and India, the current study for Indonesia is the third time that the extended water-resources-use accounting framework is applied at the provincial level. After the India study it is the second time that - in addition to the green and blue water footprint components - the grey water footprint component is included in such a study. The current study for Indonesia differs from the India study in that the latter showed export of virtual water from the most water-scarce regions (Punjab, Haryana), whereas the current study will show import of virtual water to the most water-scarce region (Java).

\section{Method and data}

For the calculation of water footprints and virtual water flows, the methodology described in Hoekstra and Chapagain $(2007,2008)$ has been used. Agricultural products can be divided in crops and livestock products. The focus in this study will be on crops. The first step in the calculation of the water footprint of a crop product is the determination of the evapotranspiration. The FAO Penman-Monteith method has been used to calculate the reference evapotranspiration, which is the evapotranspiration of reference grass in the situation with an abundance of water (Allen et al, 1998). The data for the calculation of the reference evapotranspiration are taken from CLIMWAT (FAO, 2008a) and BMG (2008). Subsequently, the reference evapotranspiration is multiplied with a crop parameter, to calculate the evapotranspiration of a crop. The crop parameters are obtained from Allen et al. (1998), Chapagain and Hoekstra (2004), IRRI (2008), Swastika et al. (2004), FAO (2008b), Taufiq et al. (2007) and Wood and Lass (1989). Calculations over the growing period are done with a time step of ten days. The crop water requirement is the summation of this potential crop evapotranspiration over the growth period. The water footprint of a crop depends on the crop water requirement and the availability of water in the soil. This water can originate from either rainwater or irrigation. The water originating from rainfall that contributes to crop growth is called green water use. The green water use is the minimum of the potential crop evapotranspiration and the effective rainfall. The effective rainfall is defined as the amount of rainfall that enters the soil and will be available in the soil for crop growth (FAO, 2008c). It is calculated according to a formula developed by the USDA Soil Conservation Service (FAO, 2008c). The rainfall data are obtained from CLIMWAT (FAO, 2008a) and BMG (2008). Irrigation water that is used for crop growth is called blue water use. The blue water use is assumed to equal the irrigation water requirement in the crop areas that are reported as "irrigated". Blue water use is assumed zero in areas that are reported as "non irrigated". The ratios of irrigated to total crop area are based on BPS (2008a) and Ministry of Agriculture (2008). The irrigation water requirement is the potential crop evapotranspiration minus the green water use. Irrigation of estate crops is not common FAO (1999), the blue component is nil for these crops. Finally, the grey water footprint of a product is an indicator of freshwater pollution that can be associated with the production of a product over its full supply chain (Chapagain et al., 2006; Hoekstra and Chapagain, 2008; Nazer et al., 2008; Van Oel et al., 2009). It is defined as the volume of freshwater that is required to assimilate the load of pollutants based on ambient water quality standards. It is calculated as the volume of water that is required to dilute pollutants to such an extent that the quality of the water remains above agreed water quality standards (Hoekstra et al., 2009). We have restricted the analysis to the 
effect of nitrates used as inorganic fertilisers in agriculture. The grey water footprint is calculated as the amount of nitrate that has leached into the groundwater multiplied with a dilution factor. The amount of nitrate that has leached into the groundwater is equal to the amount of nitrate supplied to the field times the leaching factor. Data about fertilizer use have been taken from FAO $(2005,2008 d)$. In the data there is no distinction in fertilizer use per province, therefore it is assumed that fertilizer use per hectare is the same in every province. The leaching factor is taken from Chapagain et al. (2006). The dilution factor is the inverse of the maximum acceptable level of nitrogen in the ambient water system, which is obtained from EPA (2005). The total water footprint of a product is the sum of the green, blue and grey water footprint of a product. These components are calculated by summing respectively green, blue and grey water use over the growing period and dividing those sums by the yield. The yield is determined with the production quantity and harvested area, which are taken from the Ministry of Agriculture (2008), BPS (2008b) and FAO (2008e).

The primary crops can be processed into other products. This will lead to a distribution of the water footprint of the crop over the processed products. The water footprint of a processed crop product is the water footprint of the primary crop multiplied with the value fraction and divided by the product fraction. The product fractions are obtained from FAO (2008f) and the value fractions are from Chapagain and Hoekstra (2004).

Virtual water flows are the result of trade between regions. For the calculation of the virtual water flows between Indonesian provinces the methodology described in Ma et al. (2006) has been used. The method is based on surpluses and deficits in regions. If the production is larger than the consumption of a crop there is a surplus in a province. A deficit occurs when the consumption is larger than the production. The consumption rate is based on the daily consumption per capita of protein by provinces which is derived from BPS (2008c). The consumption diet is assumed to be equal in all provinces and is derived from the national food balance (FAO, 2008e). The population by province is taken from BPS (2008d), for the calculation of the total consumption in a province. Trade will occur from regions with surpluses to regions with deficits. In this study the assumption is made that trade will first start between provinces within an island group. After this first distribution trade will occur between the remaining provinces in Indonesia. Interprovincial virtual water flows are calculated by multiplying product trade volumes by the water footprints of the traded products.

The water footprint of a province consists of an internal and external part. The internal water footprint is defined as the annual volume of provincial water resources used to produce crops consumed by inhabitants of a province. The external water footprint is defined as the annual volume of water resources used in other countries or provinces to produce crops consumed by inhabitants of the province concerned
Table 1. The average green, blue and grey water footprint for primary crops in Indonesia (2000-2004).

\begin{tabular}{lrrrr}
\hline & \multicolumn{3}{c}{ Water footprint $\left[\mathrm{m}^{3}\right.$ /ton $]$} \\
\cline { 2 - 5 } & Green & Blue & Grey & Total \\
\hline Rice & 2527 & 735 & 212 & 3473 \\
Maize & 2395 & 75 & 13 & 2483 \\
Cassava & 487 & 8 & 19 & 514 \\
Soybeans & 1644 & 314 & 0 & 1958 \\
Groundnut & 2962 & 162 & 0 & 3124 \\
Coconut & 2881 & 0 & 16 & 2896 \\
Oil palm & 802 & 0 & 51 & 853 \\
Banana & 875 & 0 & 0 & 875 \\
Coffee & 21904 & 0 & 1003 & 22907 \\
Cocoa & 8895 & 0 & 519 & 9414 \\
\hline
\end{tabular}

(Hoekstra and Chapagain, 2007). The international water flow coming into Indonesia is taken from Hoekstra and Mekonnen (2010).

\section{Results}

\subsection{Water footprint of crops per province}

Cassava has the lowest water footprint of the crops considered, namely about $500 \mathrm{~m}^{3} /$ ton, and coffee the highest, about $22900 \mathrm{~m}^{3} /$ ton. The water footprints of the most important crops averaged for Indonesia are listed in Table 1. In total terms, rice is the largest water user compared with the water use for other crops. This is caused by the high production quantity and the high water footprint per kilogram of rice produced. Rice is the most important crop in the diet of Indonesian people. The regional differences in the water footprint of crops are in some cases relatively large. These differences are caused by differences in climate and agricultural practice. Climate determines the evapotranspiration and thus influences the water footprint of crops. The average evapotranspiration within Indonesia varies between 3.5 and $5.8 \mathrm{~mm} /$ day. Agricultural practice determines yields; a high crop yield results in a relatively low water footprint of the crop.

The green component has the largest contribution to the water footprint of crops. For rice, the green component contributes $73 \%$ to the total water footprint. The blue component is $21 \%$ for rice, $16 \%$ for soybean and $5 \%$ for groundnut; for the other crops the contribution of the blue component to the water footprint is marginal. Most crops are thus mainly grown with rainwater. Blue water consumption, i.e. consumptive use of groundwater or surface water, generally has a larger effect on the environment than green water consumption, which refers to rainwater use (Falkenmark and Röckstrom, 2004). The crops rice, oil palm and cocoa have the largest grey component, because of the relatively large 


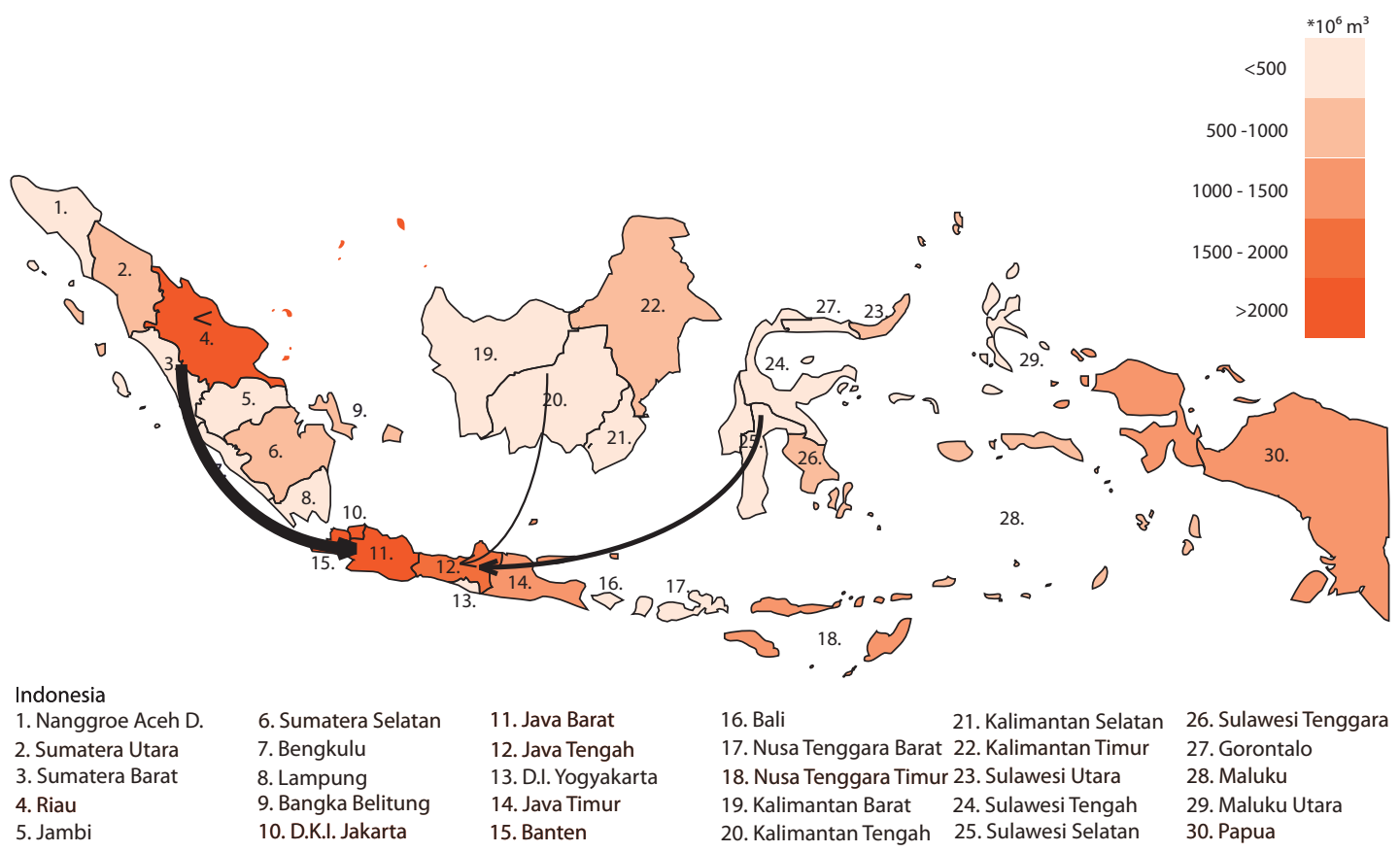

Fig. 1. Virtual water import per province with the largest net virtual water flows between island groups. Only the largest flows $\left(>10^{9} \mathrm{~m}^{3} / \mathrm{yr}\right)$ are shown.

amount of fertilizer application. This component accounts for $6 \%$ of the water footprint for these crops. For some crops irrigation or fertilizer use is not common yet. Due to the increasing crop demand and spread of technology, this may become more common in the future, in which case the pressure on the blue water resources will increase.

\subsection{Virtual water flows related to trade in crop products}

The province that has the largest virtual water outflow to other provinces is Sulawesi Selatan. This is mainly caused by the export of rice to other areas within Indonesia, most importantly Jakarta and the rest of Java. Other large exporting provinces are Kalimantan Selatan, Sumatera Barat and Nanggroe Aceh D. These provinces account for $82 \%$ of the total virtual water flow within Indonesia. These provinces have a large production and consequently a large surplus of one or more crops, so there is a large outflow of products to other provinces with deficits. Table 2 shows these virtual water flows between provinces.

The provinces that import most water in virtual form from other provinces are Jakarta, Java Barat, Riau and Banten. These provinces account for $55 \%$ of the total interprovincial virtual water import. Because of the high consumption quantity and/or the low production of crops, these provinces have a high virtual water import.

The province of Riau is a large exporting and a large importing province. This is caused by the fact that the surplus of certain crops is high while other crops are in large deficit.
Riau imports a lot of rice and cassava and it has a large surplus of coconut and palm oil.

Figure 1 shows that the largest virtual water flows between provinces all go to Java. Java is an extremely densely populated island on which natural resources are not sufficient to feed all inhabitants. To reduce the pressure on the water resources on Java, water is imported in virtual form from provinces with a lower scarcity of water. This is in contrast with the situation in India and China, where studies have shown that virtual water is exported out of water-scarce regions, putting extra pressure on the water resources in these regions (Ma et al., 2006; Kampman et al., 2008).

The island group that exports most virtual water to other countries is Sumatra (Table 3). The large flow of virtual water out of Sumatra is mainly related to the export of oil palm, coffee and coconut oil. Oil palm contributes more than $60 \%$ to the total virtual water export of Indonesia. Indonesia is the world's largest producer of oil palm and the largest part of the production is meant for the world market. Java is the only region in Indonesia with a net virtual water inflow (Table 3). In total, Indonesia exports more virtual water to other countries than it imports, resulting in a net outflow of virtual water from Indonesia.

Table 4 shows the interprovincial and international virtual water flows that can be associated with trade in various crops. Crops causing relatively large interprovincial flows of water are cassava, groundnuts, bananas and coffee. Banana is the crop with by far the largest interprovincial water flow relative to the water use for production. Soybean is the product with 
Table 2. Gross virtual water flows between provinces as an average over the years 2000-2004.

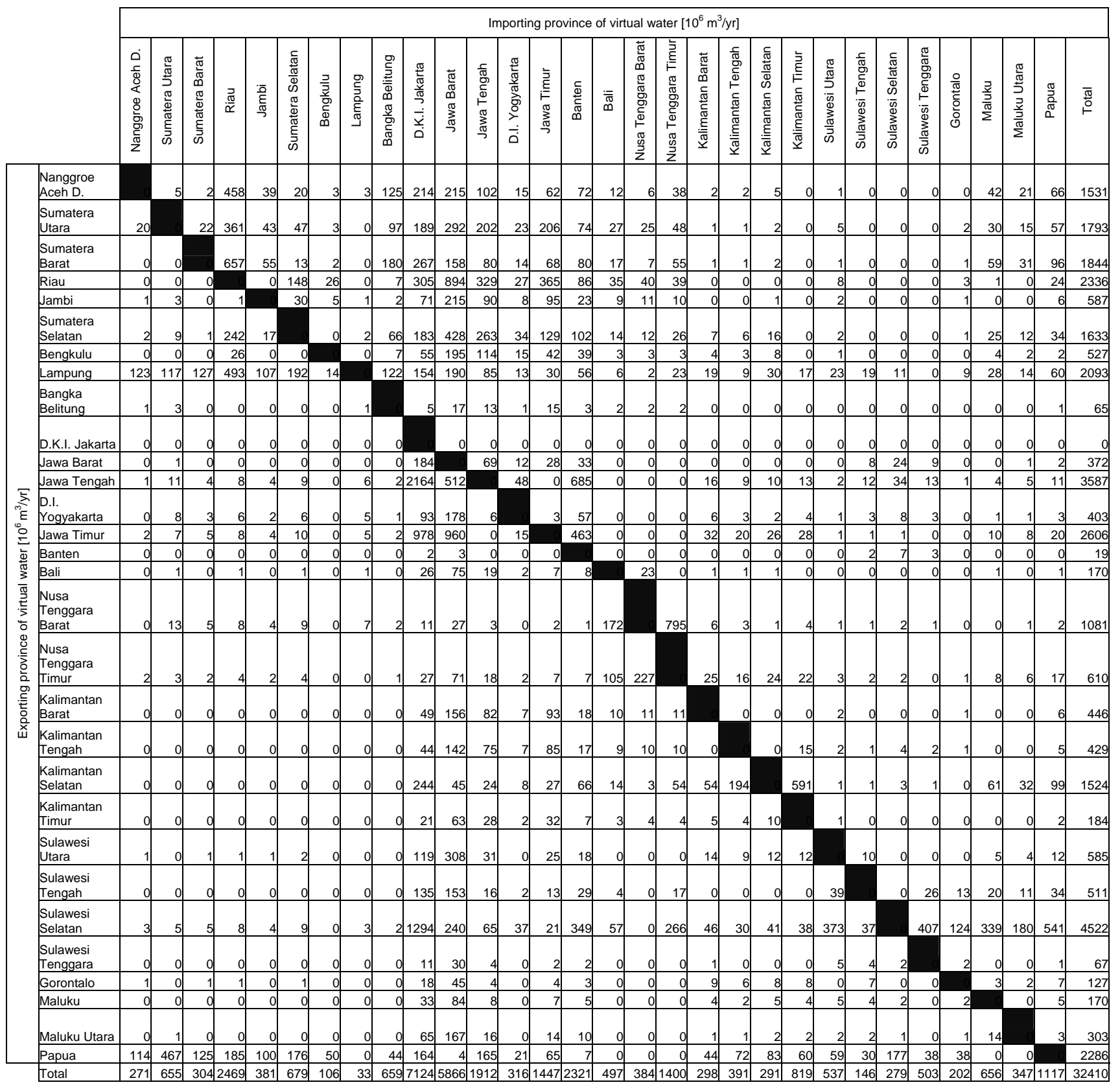

the highest international import of virtual water. The crops with a relatively large amount of virtual water that will leave the country are oil palm, coffee, coconuts and cocoa.

\subsection{Water footprint of Indonesian provinces}

The average water footprint related to the consumption of crop products in Indonesia is $1131 \mathrm{~m}^{3} / \mathrm{cap} / \mathrm{yr}$. People in Kalimantan Tengah have the largest water footprint, $1895 \mathrm{~m}^{3} / \mathrm{cap} / \mathrm{yr}$, and a person in Java Timur has the smallest water footprint, $859 \mathrm{~m}^{3} / \mathrm{cap} / \mathrm{yr}$. A person in Jakarta relies the most on external water resources. Jakarta is a large urban area with only a small area suitable for agricultural purposes. This creates the dependency on water resources of other provinces and countries. Lampung has the highest use of internal water resources (98\%). Lampung can fulfil its own needs for almost every crop, only for groundnuts and soybeans it has a small deficit. The provinces have an average internal water use of $84 \%$, for the other $16 \%$ they rely on other provinces or countries. Table 5 shows the water footprint related to the consumption of crop products per Indonesian province. 
Table 3. International virtual water flow per island group as an average over the years 2000-2004.

\begin{tabular}{lrrrr}
\hline & $\begin{array}{r}\text { Water use for } \\
\text { production }\end{array}$ & & \multicolumn{3}{c}{ International virtual water flows $\left[10^{9} \mathrm{~m}^{3} / \mathrm{yr}\right]$} \\
\cline { 3 - 5 } & & Gross virtual & Gross virtual & Net virtual \\
& {$\left[10^{9} \mathrm{~m}^{3} / \mathrm{yr}\right]$} & water export & water import & water export \\
\hline Sumatra & 116 & 29.0 & 1.3 & 27.7 \\
Java & 124 & 1.1 & 3.1 & -2.0 \\
Nusa Tenggara & 18 & 1.1 & 0.35 & 0.77 \\
Kalimantan & 32 & 5.8 & 0.40 & 5.4 \\
Sulawesi & 39 & 5.5 & 0.38 & 5.1 \\
Maluku & 4 & 0.97 & 0.15 & 0.82 \\
Papua & 2 & 0.25 & 0.16 & 0.09 \\
\hline Total & 335 & 43.7 & 5.8 & 37.8 \\
\hline
\end{tabular}

${ }^{1}$ Water use refers here to the total crop production, including crops not used for food, but for feed, seed or other purposes (see food balance sheet).

Table 4. Water use for production, interprovincial virtual water flow and international virtual water flow per crop for Indonesia for the period 2000-2004. The primary and processed crops are combined.

\begin{tabular}{lrrrr}
\hline & $\begin{array}{r}\text { Water use for } \\
\text { production }\end{array}$ & $\begin{array}{r}\text { Interprovincial } \\
\text { virtual water flow }\end{array}$ & $\begin{array}{r}\text { International virtual } \\
\text { water flow }\left[10^{9} \mathrm{~m}^{3} / \mathrm{yr}\right]\end{array}$ \\
\cline { 5 - 5 }$\left[10^{9} \mathrm{~m}^{3} / \mathrm{yr}\right]$ & 182.0 & 13.8 & 1.8 & 0.0 \\
\hline Rice (milled equivalent) & 25.3 & 3.2 & 0.2 & 0.1 \\
Maize & 9.1 & 1.6 & 0.2 & 0.3 \\
Cassava & 1.5 & 0.0 & 2.6 & 0.0 \\
Soybeans & 2.4 & 0.5 & 0.4 & 0.0 \\
Groundnuts & 47.3 & 3.7 & 0.0 & 8.6 \\
Coconuts & 44.1 & 4.3 & 0.0 & 24.0 \\
Oil palm & 3.8 & 2.5 & 0.0 & 0.0 \\
Bananas & 14.5 & 2.5 & 0.1 & 7.0 \\
Coffee & 5.3 & 0.2 & 0.5 & 3.5 \\
Cocoa & 335.3 & 32.4 & 5.8 & 43.7 \\
\hline Total & & &
\end{tabular}

${ }^{1}$ Water use refers here to the total crop production, including crops not used for food, but for feed, seed or other purposes (see food balance sheet).

Figure 2 visualizes the variation of the water footprint per capita over Indonesia. The water footprints of provinces on Java are relatively low and provinces on Kalimantan have a relatively high water footprint. The factors that determine the water footprint in general are: volume of consumption, consumption patterns, climate and agricultural practice (Hoekstra and Chapagain, 2007). Because in this study the consumption patterns (ratios between type of crops consumed) have been assumed to be the same for each province, the differences in water footprints are caused by climate, agricultural practice and consumption quantity. Agricultural practice influences the yield and thus the water footprint of crop products. On Java the yields are high, the average consumption rate is just below average and the evapotranspiration rate is lower compared to other regions, which causes the low water footprint of the population on Java.
Rice contributes $69 \%$ to the crop-related water footprint. This is caused by the relatively high water footprint per kilogram for rice, but mostly by the high consumption rate of rice in Indonesia. After rice, coconut and coconut oil have the largest contribution to the crop-related water footprint of an average Indonesian consumer.

The contribution of the green, blue and grey component to the water footprint related to the consumption of crop products is respectively $80 \%, 15 \%$ and $5 \%$. The green component has by far the largest contribution and the grey component is relatively small.

Figure 3 shows the virtual water trade balance and the water footprint for the island of Java and for Indonesia as a whole. The total virtual water import of Java is 15.6 billion $\mathrm{m}^{3} / \mathrm{yr}$, of which 12.5 billion $\mathrm{m}^{3} / \mathrm{yr}$ comes from other islands and 3.1 billion $\mathrm{m}^{3} / \mathrm{yr}$ from other 
Table 5. Water footprint related to the consumption of the selected crop products per capita for Indonesian provinces for the period 2000-2004.

\begin{tabular}{|c|c|c|c|c|}
\hline & \multicolumn{4}{|c|}{ Provincial water footprint $\left[\mathrm{m}^{3} / \mathrm{cap} / \mathrm{yr}\right]$} \\
\hline & \multirow{2}{*}{ Internal } & \multicolumn{2}{|c|}{ External } & \multirow{2}{*}{ Total } \\
\hline & & Other province & Other country & \\
\hline Nanggroe Aceh D. & 1171 & 69 & 4 & 1243 \\
\hline Sumatera Utara & 1245 & 56 & 22 & 1323 \\
\hline Sumatera Barat & 1131 & 71 & 24 & 1226 \\
\hline Riau & 663 & 498 & 79 & 1240 \\
\hline Jambi & 1288 & 158 & 38 & 1483 \\
\hline Sumatera Selatan & 1143 & 98 & 30 & 1272 \\
\hline Bengkulu & 1573 & 67 & 17 & 1657 \\
\hline Lampung & 1113 & 5 & 19 & 1136 \\
\hline Bangka Belitung & 360 & 732 & 115 & 1207 \\
\hline D.K.I. Jakarta & 5 & 849 & 121 & 974 \\
\hline Java Barat & 708 & 164 & 30 & 902 \\
\hline Java Tengah & 1152 & 61 & 15 & 1228 \\
\hline D.I. Yogyakarta & 875 & 101 & 11 & 986 \\
\hline Java Timur & 815 & 42 & 2 & 859 \\
\hline Banten & 789 & 287 & 55 & 1130 \\
\hline Bali & 923 & 158 & 29 & 1110 \\
\hline Nusa Tenggara Barat & 1332 & 96 & 6 & 1433 \\
\hline Nusa Tenggara Timur & 865 & 354 & 58 & 1277 \\
\hline Kalimantan Barat & 1639 & 74 & 26 & 1740 \\
\hline Kalimantan Tengah & 1641 & 211 & 44 & 1895 \\
\hline Kalimantan Selatan & 1337 & 97 & 26 & 1461 \\
\hline Kalimantan Timur & 1096 & 334 & 56 & 1485 \\
\hline Sulawesi Utara & 1021 & 267 & 47 & 1335 \\
\hline Sulawesi Tengah & 1332 & 66 & 22 & 1420 \\
\hline Sulawesi Selatan & 1249 & 35 & 14 & 1297 \\
\hline Sulawesi Tenggara & 1089 & 276 & 50 & 1415 \\
\hline Gorontalo & 905 & 242 & 36 & 1182 \\
\hline Maluku & 360 & 544 & 80 & 984 \\
\hline Maluku Utara & 569 & 442 & 72 & 1082 \\
\hline Papua Barat & 475 & 503 & 70 & 1048 \\
\hline Indonesia & 946 & 157 & 28 & 1131 \\
\hline
\end{tabular}

countries. The total virtual water export from Java is 1.6 billion $\mathrm{m}^{3} / \mathrm{yr}$, of which 0.5 billion $\mathrm{m}^{3} / \mathrm{yr}$ goes to other islands and 1.1 billion $\mathrm{m}^{3} / \mathrm{yr}$ to other countries. The total water footprint of the Javanese population, insofar related to consumption of crop products, is 114.4 billion $\mathrm{m}^{3} / \mathrm{yr}, 13 \%$ of which is external. Java thus depends on external water resources, most of which comes from other islands. As for Indonesia as a whole, the dependency on external water resources is minimal. On contrary, the country exports a significant amount of water in virtual form.

\section{Conclusions and discussion}

The average water footprint related to the consumption of crop products in Indonesia is $1131 \mathrm{~m}^{3} / \mathrm{cap} / \mathrm{yr}$, but there are large regional differences. The water footprint in Java Timur is the lowest, namely $859 \mathrm{~m}^{3} / \mathrm{cap} / \mathrm{yr}$, and the highest water footprint can be found in Kalimantan Tengah, $1895 \mathrm{~m}^{3} / \mathrm{cap} / \mathrm{yr}$. Because the consumption pattern is assumed the same in each province, the differences in water footprint are caused by climate, agricultural practice and consumption volume. The biggest contribution to the water footprint per capita is from rice. This is caused by the high consumption rate and the relatively high water footprint of rice.

The water footprint of crops strongly varies within the country. For instance, of all large rice producing provinces, the provinces on Java and Bali have the lowest water footprint. The water footprint of one kilogram of rice produced on Java or Bali is almost half the amount of the water footprint of rice produced on Kalimantan, the Maluku islands 


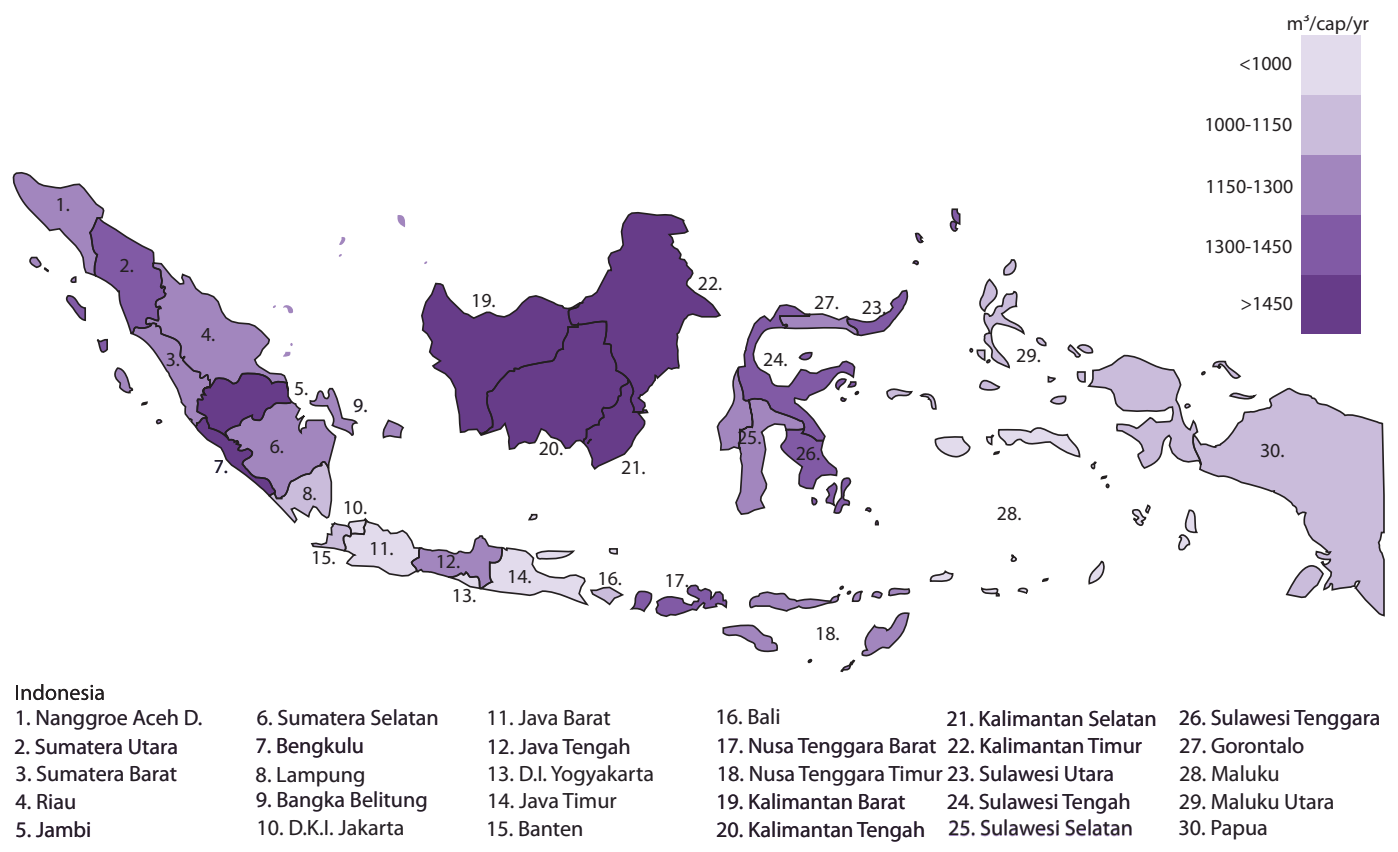

Fig. 2. Water footprints of Indonesian provinces per capita related to crop products for the period 2000-2004.
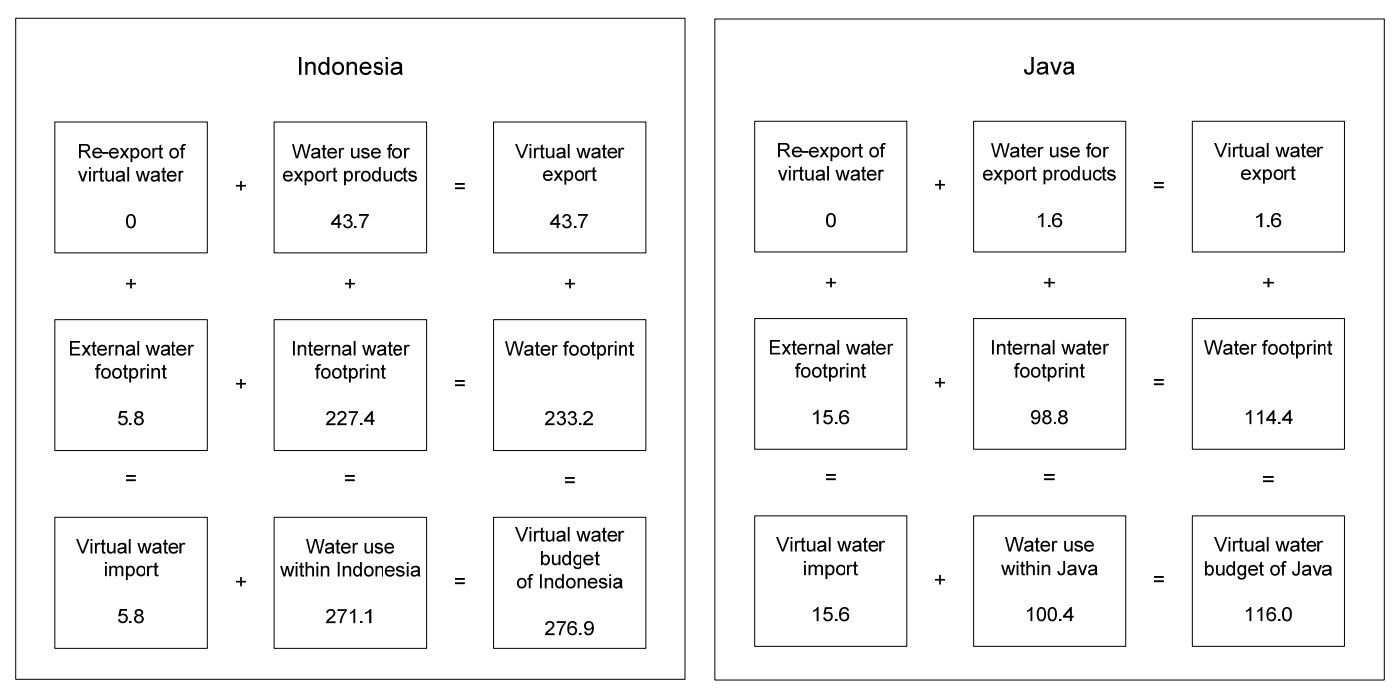

Fig. 3. The virtual water trade balance and water footprint for Indonesia and the island of Java. The numbers refer to water volumes in $10^{9} \mathrm{~m}^{3} / \mathrm{yr}$. The water use refers to the production for food only, not to the production for feed, seed and other uses.

or Papua. This finding is consistent with the expectation that water use efficiency is highest in places where water is most scarce.

The green water component has the largest contribution to the water footprint of crops in Indonesia. For most crops the blue water use is less than $10 \%$ of the total water footprint, only for rice and soybeans the blue water contribution is higher. The grey component in the water footprint of crops in Indonesia is relatively low, it contributes to at most $6 \%$.
The interprovincial virtual water flows are primarily caused by trade in rice. The crops cassava, coconut, bananas and coffee have the largest interprovincial flow relative to the water use for production. Sulawesi Selatan has the largest contribution to the virtual water export to other provinces. The flow out of this province exists primarily of water virtually embedded in rice. Large importing provinces are Jakarta, Java Barat, Riau and Banten. The largest flow of net virtual water is from Sumatra to Java. Java, the most waterscarce island, has a net virtual water import and the most 
significant external water footprint, which does relieve the water scarcity on this island. Sumatra exports most virtual water to other countries. The large flow of virtual water out of Sumatra is mainly related to the products palm oil, coffee and coconut oil.

Provinces depend highly on internal water resources. On average $84 \%$ of the water footprint consists of internal water, the flow of virtual water between provinces is low. Trade is essential, however, to supply food to the most densely populated areas where water scarcity is highest (Java). Water scarcity on Java has been reduced by externalising the water footprint of the consumers on Java to other provinces.

This paper illustrates how the framework of water footprint accounting can be applied at sub-national level. Water footprint accounts provide a broader information base than traditional water use accounts, which show water withdrawals alone. Water footprint accounts show not only blue but also green and grey water. Besides, water footprint accounts show to which extent the water use in a certain province relates to provincial consumption and to which extent to export. The sort of new data presented here may have implications for water policy, but a few disclaimers are in place. First of all, the data presented in this study are subject to a number of assumptions and limitations formulated in the method and data section. The results are probably most vulnerable to the assumptions that actual irrigation in irrigated areas equals the irrigation requirements and that nitrogen application per hectare is the same in every province. A serious limitation is that the grey water footprint has been based on a consideration of nitrogen only. For the purpose of actual policy making, refinements of the current study are necessary. Besides, the sort of data presented in this study extend the database on "water use", but obviously still provides partial information. For a proper assessment of the economic, social and environmental implications of the green, blue and grey water footprints of crops in Indonesia, further research is required. This would include a comparison of local water footprints to locally available water resources and an evaluation of local water use efficiency, equitability and sustainability.

Acknowledgements. The authors are grateful to LabMathIndonesia, Bandung, Indonesia, for supporting this work and to Badan Meteorologi dan Geofisika, Jakarta, Indonesia, for making data available for this study.

Edited by: P. van der Zaag

\section{References}

ADB: Indonesia: strategic vision for agriculture and rural development, Asian Development Bank, Manila, Philippines, 2006.

Allen, R. G., Pereira, L. S., Raes, D., and Smith, M.: Crop evapotranspiration: Guidelines for computing crop water requirements, FAO Irrigation and Drainage Paper 56, Food and Agricultural Organization, Rome, Italy, 1998.
BMG: Climatic data from weather stations over Indonesia, Badan Meteorologi dan Geofisika, Jakarta, Indonesia, 2008.

BPS: Land utilization by province 2005 (ha), Badan Pusat Statistik, Jakarta, http://www.bps.go.id, last access: 6 May 2008, 2008a.

BPS: Production and Area by crop 1995-2006, Badan Pusat Statistik, Jakarta, http://www.bps.go.id, last access: 11 June 2008, 2008b.

BPS: Daily per capita consumption of protein 2002-2006, Badan Pusat Statistik, Jakarta, http://www.bps.go.id, last access: 15 December 2008, 2008c.

BPS: Population of Indonesia by Province 1971, 1980, 1990, 1995 and 2000, Badan Pusat Statistik, Jakarta, http://www.bps.go.id/eng/tab_sub/view.php?tabel=1\&daftar= 1\&id_subyek=12\&notab=1, last access: 23 April 2008, 2008d.

Chapagain, A. K. and Hoekstra, A. Y.: Water footprints of nations, Value of Water Research Report Series No. 16, UNESCO-IHE, Delft, the Netherlands, 2004.

Chapagain, A. K., Hoekstra, A. Y., Savenije, H. H. G., and Gautam, R.: The water footprint of cotton consumption: An assessment of the impact of worldwide consumption of cotton products on the water resources in the cotton producing countries, Ecol. Econ., 60, 186-203, 2006.

Chapagain, A. K. and Orr, S.: UK Water Footprint: The impact of the UK's food and fibre consumption on global water resources, WWF-UK, Godalming, UK, 43 pp., 2008.

EPA: List of drinking water contaminants: ground water and drinking water, US Environmental Protection Agency, Washington DC, USA, http://www.epa.gov/safewater/standards.html last access: 10 June 2008, 2005.

Falkenmark, M. and Rockström, J.: Balancing water for humans and nature: The new approach in ecohydrology, Earthscan, London, UK, 247 pp., 2004.

FAO: Irrigation in Asia in figure, Water Reports 18, Food and Agricultural Organization, Rome, Italy, 236 pp., 1999.

FAO: Fertilizer use by crop in Indonesia, Land and Plant Nutrition Management Service, Land and Water Development Division, Food and Agricultural Organization, Rome, Italy, 78 pp., 2005.

FAO: CLIMWAT database, Food and Agricultural Organization, Rome, http://www.fao.org/nr/water/infores_databases_climwat. html, last access: 17 April 2008, 2008a.

FAO: AQUASTAT database, Food and Agricultural Organization, Rome, www.fao.org/nr/water/aquastat/main/index.stm, last access: 8 May 2008, 2008b.

FAO: CROPWAT model, Food and Agricultural Organization, Rome, www.fao.org/nr/water/infores_databases_cropwat. html, last access: 17 April 2008, 2008c.

FAO: Fertistat database, Food and Agricultural Organization, Rome, www.fao.org/ag/agl/fertistat, last access: 15 May 2008, 2008 d.

FAO: FAOSTAT database, Food and Agricultural Organization, Rome, http://faostat.fao.org/, last access: 30 June 2008, 2008e.

FAO: Technical conversion factors for agricultural commodities, Food and Agricultural Organization, Rome, Italy, 2008f.

Hoekstra, A. Y.: Virtual water trade: Proceedings of the International Expert Meeting on Virtual Water Trade, Value of Water Research Report Series No. 12, UNESCO-IHE, Delft, The Netherlands, 2003. 
Hoekstra, A. Y. and Chapagain, A. K.: Water footprints of nations: water use by people as a function of their consumption pattern, Water Resour. Manag., 21(1), 35-48, 2007.

Hoekstra, A. Y. and Chapagain, A. K.: Globalization of water: Sharing the planet's freshwater resources, Blackwell Publishing, Oxford, UK, 232 pp., 2008.

Hoekstra, A. Y. and Mekonnen, M. M.: International virtual water flow between nations (1996-2005), in preparation, 2010.

Hoekstra, A. Y., Chapagain, A. K., Aldaya, M. M., and Mekonnen, M. M.: Water footprint manual: State of the art 2009, Water Footprint Network, Enschede, the Netherlands, www. waterfootprint.org/downloads/WaterFootprintManual2009.pdf, last access: 22 December 2009, 2009.

Kampman, D. A., Hoekstra, A. Y., and Krol, M. S.: The water footprint of India, Value of Water Research Report Series No.32, UNESCO-IHE, Delft, The Netherlands, 2008.

IRRI: World rice statistics, International Rice Research Institute, Manila, www.irri.org/science/ricestat/, last access: 24 April 2008, 2008

Ma, J., Hoekstra, A. Y., Wang, H., Chapagain, A. K., and Wang, D.: Virtual versus real water transfers within China, Philos. T. R. Soc. Lon. B, 361(1469), 835-842, 2006.

Minister of Agriculture: Indonesian Agricultural Development Plan for 2005-2009, Ministry of Agriculture, Republic of Indonesia, Jakarta, Indonesia, 2006.

Ministry of Agriculture: Agricultural Statistical Database, Ministry of Agriculture, Republic of Indonesia, Jakarta, http://database. deptan.go.id/bdsp/index-e.asp, last access: 11 June 2008, 2008.
Nazer, D. W., Siebel, M. A., Van der Zaag, P., Mimi, Z., and Gijzen, H. J.: Water footprint of the Palestinians in the West Bank, J. Am. Water. Resour. A., 44(2), 449-458, 2008.

Swastika, D. K. S., Kasim, F., Sudana, W., Hendayana, R., Suhariyanto, K., Gerpacio, R. V., and Pingali, P. L.: Maize in Indonesia: Production systems, constraints, and research priorities, International Maize and Wheat Improvement Center, Mexico City, Mexico, 2004.

Taufiq, A., Rahmianna, A. A., Hardaningsih, S., and Rozi, F.: Increasing groundnut yield on dryland Alfisols in Indonesia, Sat ejournal, 5, 3 pp., 2007.

Van Oel, P. R., Mekonnen, M. M., and Hoekstra, A. Y.: The external water footprint of the Netherlands: Quantification and impact assessment, Value of Water Research Report Series No. 33, UNESCO-IHE, Delft, The Netherlands, 2008.

Verma, S., Kampman, D. A., Van der Zaag, P., and Hoekstra, A. Y.: Going against the flow: A critical analysis of inter-state virtual water trade in the context of India's National River Linking Programme, Phys. Chem. Earth, 34, 261-269, 2009.

Wood, G. A. R. and Lass, R. A.: Cocoa, tropical agricultural series, Longman, London, UK, 640 pp., 1989.

World Water Council: Water resources management towards enhancement of effective water governance on Indonesia, Republic of Indonesia, Jakarta, Indonesia, 2003. 